Res Publica Revista de Historia de las Ideas Políticas

ISSN: $1131-558 \mathrm{X}$

\title{
F. Vázquez García, Cómo hacer cosas con Foucault. Instrucciones de uso, Madrid, Dado Ediciones, 2021, 246 pp.
}

Estamos frente al tercer lanzamiento de la colección "Filosofía y sociedad" de Dado Ediciones, el primer monográfico después de dos libros colectivos: Foucault y la historia de la filosofía, que bajo la dirección de José Luis Villacañas y Rodrigo Castro Orellana recoge las conferencias presentadas en el IV Congreso Internacional "La actualidad de Michel Foucault" organizado por la Facultad de Filosofía de la Universidad Complutense de Madrid; y Fue solo un comienzo. Pensar el 68 hoy, con Emmanuel Chamorro y Anxo Garrido como editores encargados. Dado Ediciones puso como meta de esta reciente colección el abordar las realidades sociales a través de una "caja de herramientas" conceptual, un instrumental refinado y riguroso que supere la comprensión de la filosofía como un compendio de discursos autorreferenciales y la de las ciencias sociales como disciplina que puede prescindir de un aparato teórico riguroso. Pero con este tercer lanzamiento, a manos del catedrático Vázquez García, se hace algo un tanto distinto, pero fundamental para cumplir dicha meta: Cómo hacer cosas con Foucault articula un "manual de instrucciones" para el uso de esa "caja de herramientas", y en ese sentido puede ser considerado el material metodológico por excelencia de este nuevo proyecto editorial.

Puede que la visión de un determinado corpus bibliográfico como "caja de herramientas" sea uno de los tópicos foucaultianos más manidos, pero esto no quiere decir que la metáfora sea desafortunada. Muy por el contrario, ella, además de haber sido sugerente, promoviendo dentro y fuera de la Academia una particular forma pragmática de vincularse con la filosofía, también atina del todo representando el propio quehacer intelectual de Foucault -no en balde él mismo se la apropia, después de ser sugerida por Deleuze para hacer alusión a la obra de su colega. Aún así, tal como sostiene Vázquez García en las primeras páginas del texto que aquí nos concierne, se corre el peligro de pensar que con dicha metáfora se está dando licencia para que con el material al que se refiere se haga cualquier cosa, del modo que se desee y para cualquier finalidad, sin que exista ningún criterio que permita distinguir el uso del abuso, peligro que se agudiza mientras más se difunde el tópico sin una adecuada comprensión de la instrumental que Foucault ha puesto a nuestra disposición, de su funcionamiento, sus límites, su contexto y su constitución. De hecho, no han faltado críticas que apuntan a la "excesiva facilidad" (p. 13) de la metáfora, y ciertos abusos vinculados a un conocimiento deficiente de la obra y metodología de Foucault o a la pretensión de hacerse con bienes simbólicos que brinden algún prestigio en la esfera académica o política han contribuido a dar peso a esas críticas. No obstante, la solución de Vázquez García no radica en plantear un uso dogmático u ortodoxo del instrumental foucaultiano, y más bien advierte contra su "mera transferencia mecánica sin ponerlo a prueba” (p. 41). Aún más, Cómo hacer cosas con Foucault puede entenderse como las instrucciones de un tipo de uso entre otros, uno que Vázquez García denomina "programático", y que se caracteriza por la adopción consciente del método arqueogenealógico. Mas no se dejan de señalar otros tipos de usos que no son de por sí inadecuados e incluso han logrado ser fructuosos, tal como el "segmentario", el "heurístico" y el "poiético-praxeológico"; del mismo modo que pueden existir malos usos programáticos, justamente por llevar a cabo una utilización rígida y mimética (p. 34).

Esta guía para un apropiado uso programático del corpus foucaultiano está dividida en tres segmentos: análisis de problematizaciones o historia de presente, análisis del discurso o arqueología y análisis de las relaciones de poder o genealogía, cada uno ampliamente ejemplificado, tanto con las obras de Foucault, como, sobre todo, con un texto reciente del propio Vázquez García, Pater infamis. Genealogía del cura pederasta en España (1880-1912), en donde su autor aplica con rigor el método que expone en dicha guía. Lo primero que se hace en el primer apartado, antes del esclarecimiento del significado de esa sustantivación deverbal del vocablo problematizar, es indicar algunos tips que permiten familiarizar al lector con la forma de proceder de Foucault, tales como la atención a la singularidad del presente, buscar contingencias en vez causalidades o hacer epojé de juicios morales o políticos. Ya desplegados estos procedimientos, se explica la "problematización", que es el objeto propio de la metodología foucaultiana, como el ejercicio de tomar distancia de los hechos entendidos como obvios, interrumpiendo la forma espontánea de considerarlos, para luego plantearlos luego de un modo distinto. El segundo apartado, el dedicado a la arqueología, comienza con la dilucidación de la noción sobre la 
que esta se sostiene, la de "discurso", entendiéndolo no como código de signos subyacente a las prácticas, sino él mismo como práctica, como "una actividad pública y material que establece las condiciones de lo que puede ser pensado y por lo tanto practicado en un momento dado" (p. 93). Sobre esta base se explica su funcionamiento, su "descripción pura de los acontecimientos discursivos" (p. 129), distinguiéndolo, por ejemplo, de la labor hermenéutica, en tanto que no se trata de interpretar documentos, sino más bien, en todo caso, de organizarlos, recortarlos, distribuirlos, repartirlos, cotejarlos, distinguirlos, fijarlos en unidades o describir sus relaciones, y así poder reconocer temas claves -vinculados a palabras relevantes o imágenes recurrentes-y describir las instituciones que adquieren poder articulándose a partir de las prácticas discursivas, así como sus efectos de verdad y de prescripción. Finalmente, el tercer apartado, el dedicado a la genealogía -que, según argumenta Vázquez García, actúa en conjunto con el método arqueológico- se abre con un rápido comentario del texto foucaultiano Nietzsche, la genealogía, la historia, el cual hace referencia a su vez a la tipología apuntada por el filósofo alemán en su Segunda consideración intempestiva, sobre la utilidad y los perjuicios de la historia para la vida, en el cual se distinguen tres tipos de prácticas historiográficas: la "historia monumental", la "historia anticuaria" y la que sería la propuesta propiamente nietzscheana, la "historia crítica", cuyos rasgos coinciden con la labor genealógica. Dicha labor, estaría al servicio de la vida, le sería útil, de tres modos distintos: como liberación de las falsas continuidades históricas, como liberación de las presuntas finalidades históricas y como liberación de las verdades dadas por sentadas. $\mathrm{Su}$ funcionamiento se sostendría sobre una muy distintiva noción de "poder" -fundamental en la obra de Foucault y explicada brevemente, pero con claridad y rigurosidad por Vázquez García-, en tanto que es a través del examen de las relaciones de poder, en cualquiera de sus formas -jurídicas, disciplinarias, securitarias e incluso éticas, entendiendo lo ético como plegamiento del poder hacia la mismidad-, lo que permitiría percibir las contiendas de donde brotan los discursos que la arqueología describe.
Así pues, podemos fácilmente percatarnos de que no estamos aquí, por ejemplo, frente al intento de establecer cuáles son los adecuados motivos morales o políticos de los que hay que partir para usar a Foucault -lo que para el autor sería más bien una contrainstrucción (pp. 69-70)-, y menos aún frente a un simplificador manual para dummies. Muy por el contrario, Vázquez García nos brinda una sobria y detallada explicación de la constitución y funcionamiento de esa compleja tecnología foucaultiana que es el método arqueogenealógico, explicación siempre acompañada de ejemplos de uso, los del propio Vázquez García y también los de Foucault, los cuales, por momentos, se nos aparecen como las indispensables ilustraciones de los manuales de instrucción de los diversos aparatos que manejamos día a día, esos dibujos que aclaran lo que la palabra por sí sola apenas nos mostraba oscuramente. Pero, como si esto no fuera suficiente, Cómo hacer cosas con Foucault muestra algo más: nos da noticia del material del que están hechos estos artificios foucaultianos, la base conceptual que las constituye, trátese bien de la noción que sirve de pilar teórico para el ejercicio arqueológico, a saber, la de "acontecimiento discursivo", topos en el cual se daría y se delimitaría lo que puede ser pensado y practicado; o la particular noción de "poder" que maneja el filósofo parisino, fundamento conceptual del método genealógico de herencia nietzscheana. De este modo, Vázquez García presenta una obra auténticamente armónica con el espíritu foucaultiano, en tanto que está pensando para el uso, para la acción, para la realización de cosas -tal como sugiere su propio título-; pero es también una obra infoucaultiana, dado que su utilidad radica en hacer que la obra de Foucault, que se pensó a sí misma para el uso, materialice su pragmática finalidad, o, dicho de un modo pindárico, que ella llegue a ser lo que en efecto es; y a su vez alcanza a ser, en cierto sentido, un libro que, al poner sobre la mesa las bases filosóficas de la metodología a explicar, los principios teóricos que le dan solidez y al señalar las influencias que le dieron forma, así como las tradiciones que confronta, sienta las bases para futuras problematizaciones metodológicas.

Juan Horacio de Freitas 